\title{
RELATIONSHIPS BETWEEN FORAGE YIELD AND QUALITY OF CYNOSURETUM CRISTATI TYPE MEADOWS AND DIFFERENT RATES OF NITROGEN FERTILIZER $^{1}$
}

\author{
S. Vučković, A. Simić, N. Djordjević ${ }^{2}$
}

Abstract: The investigation was carried out at Sjenica-Pester plateau in 2002-2003 on a natural $C y$ nosuretum cristati type meadow, in a place called Vrujci at $1158 \mathrm{~m}$ above the sea level. Forage yield and chemical composition were correlated with different rates of nitrogen fertilizer $\left(0,40,80,120\right.$ and $\left.160 \mathrm{~kg} \mathrm{ha}^{-1}\right)$. The obtained data have indicated that nitrogen fertilizer had a positive effect on increasing the yield, crude protein, ash and fat content, while the negative on cellulose content. The maximum DM yield was obtained in the test with $160 \mathrm{~kg} \mathrm{ha}^{-1}$ nitrogen, amounting to $4.44 \mathrm{tha}^{-1}$ for two years, which was an increase of 2,04 $\mathrm{tha}^{-1}$ or $85.0 \%$ over the control. Nitrogen application correlated strongly $(r>0.9)$ and significantly $(\mathrm{P}=0.01)$ with dry matter yield and chemical composition. Positive correlation coefficients were obtained between $\mathrm{N}$ application and dry matter yield, crude protein, ash, fat $\left(\mathrm{r}=0.999^{* *}, 0.988^{* *}, 0.988^{* *}, 0.998^{* *}\right.$, respectively $)(\mathrm{P}=0.01)$. Negative correlation coefficient was obtained between $\mathrm{N}$ application and crude fibre (cellulose), $\left(\mathrm{r}=-0.998^{* *}\right)$ $(\mathrm{P}=0.01)$

Keywords: forage quality, DM yield, $\mathrm{N}$ application, relationships

\section{Introduction}

Natural meadows occupy large areas in hilly-mountains regions of Serbia, and they are of a considerable importance for forage and soil utilization and protection. Owing to poor care and bad utilization natural meadows are rather degraded, low productive and worse quality. The results of many researchers in the world show that different types of meadows and pastures respond differently to given measures and systems of improvement, because of the specific biological properties of the grasses, ecological conditions, methods of utilization, as well as other factors. The basic measure for the improvement of meadows and pastures is fertilization. Knowledge of optimal fertilization is indispensable for better grassland utilization and developing an optimal feeding regime for ruminants. Thus, nitrogen fertilizers extend vegetation period and increase the growth rate of grasses which has a favorable effect on the hay production and total yield (Chamble et al., 1953). Quality of forage obtained from a mountain pasture is influenced by harvesting phenophase and fertilizers (Sima, 2002). According to Alibegović - Grbić (2003), fertilizing with N in Bosnia and Herzegovina resulted in increased total protein yield. This result was more a consequence of increased DM yield than of higher protein content in the DM. The results of many tests performed in Serbia show that nitrogen fertilizer have a positive effect on increasing the yield, crude protein, ash and fat content, while the negative on cellulose content (Vučković et al., 2004).

Therefore, with this research we wanted to investigate the influence and the effect of nitrogen fertilization on yield and quality of natural meadow Cynosuretum cristati under the ecological and economical conditions of Serbia, being of importance both for science and for practice.

\section{Material and methods}

The research was carried out on the natural meadows in the hilly mountainous region of Serbia Sjenica-Pester Plateau. In 2002-2003, trials were conducted on a natural Cynosuretum cristati type meadow, which was situated $1158 \mathrm{~m}$ above the sea level. Before designing the experiment, soil analysis were made. The plot experiment was designed as complete blocks with four replications. The investigation was made with five nitrogen fertilizer levels $\left(0,40,80,120\right.$ and $\left.160 \mathrm{~kg} \mathrm{ha}^{-1}\right)$. All the fertilizers were applied directly on the soil surface after snow melting (at the beginning of May). The change of the grass cover was established

1 Original scientific paper - Originalni naučni rad

2 Dr Savo Vuckovic associated professor, mr Aleksandar Simic, assistant, Nenad Djordjevic, assistant professor, Faculty of Agriculture, Zemun - Belgrade 
through a botanical analysis of green mass. Chemical composition of the DM is represented by CP, ash, fat and cellulose content. DM yield was determined on the basis of total DM amount per plot and calculated as DM yield ha ${ }^{-1}$. Samples were analyzed in the Institute laboratory, according to the standard methods, and data was calculated by Statistica 5.0 Program.

\section{Survey of natural conditions}

Observation of important meteorological elements was done for 2002-2003 only (Table 1). It may be seen that the mean monthly and annual temperatures are rather low. The mean annual air temperature was $7.66{ }^{\circ} \mathrm{C}$ in 2002 and $6.43{ }^{\circ} \mathrm{C}$ in 2003. Late spring frost occurs even in May (often even later), while starting in the autumn during September and October.

The amount of precipitation (Table 1) is relatively high in this region. Although the amount of precipitation has a great effect on the productivity of meadows and pastures, particularly during vegetation, it is frequently not well distributed on Sjenica-Pester Plateau. This results from a marked fall of temperature often following rainy periods which retards growth and development of grasses hence reducing the productivity of the vegetative mass.

The meadow and pasture vegetation of Cynosuretum cristati on Sjenica-Pester Plateau is formed on humus-silicate soil (Ranker). These are shallow to medium deep soils, skeletoid to different degrees, very humid and acid (Table 2).

Table 1. Mean monthly temperatures and month total precipitation during 2002 and 2003

\begin{tabular}{|c|c|c|c|c|c|c|c|c|c|c|c|c|c|}
\hline Year & I & II & III & IV & V & VI & VII & VIII & IX & $\mathrm{X}$ & XI & XII & I-XII \\
\hline \multicolumn{14}{|c|}{ Temperatures $\left({ }^{\circ} \mathrm{C}\right)$} \\
\hline 2002 & -5.5 & 2.1 & 4.3 & 6.3 & 12.6 & 15.7 & 17.4 & 15.7 & 10.3 & 8.3 & 5.2 & -0.5 & 7.66 \\
\hline 2003 & -1.8 & -8.3 & -0.5 & 4.9 & 14.2 & 16.2 & 16.9 & 18 & 10.7 & 7 & 4.8 & -4.9 & 6.43 \\
\hline \multicolumn{14}{|c|}{ Amount of precipitation (mm) } \\
\hline 2002 & 21.8 & 31.3 & 58.4 & 85.7 & 110 & 21.1 & 118 & 73.7 & 120 & 99.4 & 35.1 & 67.3 & 842 \\
\hline 2003 & 133 & 46.7 & 6.4 & 52.4 & 64.9 & 77.1 & 63.2 & 63.4 & 68 & 148 & 31 & 49 & 803 \\
\hline
\end{tabular}

Table 2. Chemical properties of the soil

\begin{tabular}{cccc}
\hline & & \multicolumn{3}{c}{$\mathrm{mg} / 100 \mathrm{~g}$ soil } \\
\cline { 3 - 4 } $\mathrm{pH}\left(\mathrm{H}_{2} \mathrm{O}\right)$ & Humus $(\%)$ & $\mathrm{P}_{2} \mathrm{O}_{5}$ & $\mathrm{~K}_{2} \mathrm{O}$ \\
5,2 & 7.5 & 1,1 & 9,6 \\
\hline
\end{tabular}

Results and discussion

The effects of nitrogen fertilizers on meadow-pasture vegetation are complex. The grass cover responds not only in yield but also in composition: the rations between individual elements of the plant association change and by permanent use of nitrogen fertilizers it is possible to achieve substantial changes in the association. The obtained data indicate that nitrogen fertilization has considerable influence on natural meadow Cynosuretum cristati, especially on yield and quality DM as well as on the botanical composition change.

\section{Botanical composition of the sward}

There is a high domination of Poaceae in the botanical composition $(48,40-56,04 \%)$. The most of grasses are of moderate or of lower feeding value (Table 3). As a second, there are other species (42.0$34,74 \%)$ among which dominate species with no feeding value. Fabaceae participate with (9.6\%-9.2\%), among which Genista sagittalis, is the most numerous one. Other legumes are of a good feeding value. By the increase of nitrogen fertilization level, the quantity of grass, especially those of a better quality, is improved, while legumes and other herbages are decreased. 


\begin{tabular}{lcc}
\hline \multicolumn{3}{c}{ Table 3. Botanical composition of the sward } \\
\hline Plants sward in \% of mass & 2002 & 2003 \\
& & 56.04 \\
Poaceae & 48.40 & 34,74 \\
Other species & 42.00 & 9.20 \\
Fabaceae & 9.60 & \\
\hline
\end{tabular}

\section{Dry matter yield and chemical composition}

The obtained data indicate that nitrogen fertilizer had a favorable effect on increasing the yield (Table 4). The maximum yield of DM was obtained in the test with (160 kg ha-1 nitrogen), amounting to 4.44 $\mathrm{t} \mathrm{ha}^{-1}$ for two years, which was an increase of $2,04 \mathrm{tha}^{-1}$ or $85.0 \%$ over the control. However, it was observed that the effect of the highest dose of nitrogen fertilizer varied from 2002 to 2003 , depending primarily on the amount of precipitation during vegetation. Although the total yield of DM per unit area was less in a year with the more arid conditions, the percentage above the control was higher in the dry year than in the wet year. Thus, in the dry year 2003 the yield was higher by $153 \%$, while in 2002 which was a wet year, the increase was only $50 \%$. These results show that fertilization not only gives higher yields but also stabilizes fodder production, since better nourished grasses use water more economically.

Table 4. Dry matter yield and chemical composition of the meadow type Cynosuretum cristati as affected by different rates of nitrogen fertilizer during 2002-2003

\begin{tabular}{|c|c|c|c|c|c|}
\hline \multirow{2}{*}{$\begin{array}{l}\text { Fertilizer } \\
\mathrm{N}\left(\mathrm{kg} \mathrm{ha}^{-1}\right)-\end{array}$} & \multirow{2}{*}{$\begin{array}{l}\mathrm{DM} \\
\left(\mathrm{t} \mathrm{ha}^{-1}\right)\end{array}$} & $\mathrm{CP}$ & Ash & Fat & Cellulose \\
\hline & & \multicolumn{4}{|c|}{$\left(\mathrm{g} \mathrm{kg}^{-1} \mathrm{DM}\right)$} \\
\hline 0 & 2.40 & 80.1 & 54.25 & 14.1 & 338.35 \\
\hline 40 & 3.68 & 92.9 & 56.5 & 22.45 & 321.35 \\
\hline 80 & 4.10 & 112 & 61.45 & 27.1 & 309.6 \\
\hline 120 & 4.25 & 116.3 & 67.1 & 30.45 & 290.9 \\
\hline 160 & 4.44 & 135.45 & 69.1 & 32.9 & 279 \\
\hline Average & 3.77 & 107.35 & 61.68 & 25.4 & 307.84 \\
\hline$L S D_{005}$ & 0.22 & 4.32 & 1.52 & 3.44 & 7.15 \\
\hline
\end{tabular}

Forage quality of natural Cynosuretum cristati type meadow was substantially affected by different rates of nitrogen fertilizer (Table 4). Increasing rate of $\mathrm{N}$ application increased the protein, ash, fat content; on average, and reduced the cellulose content. Major components of quality for the lowest and highest $\mathrm{N}$ rates respectively were: protein 80.1 and $135.45 \mathrm{~g} \mathrm{~kg}^{-1}$, ash 54.25 and $69.1 \mathrm{~g} \mathrm{~kg}^{-1}$ and fat 14.1 and $32.9 \mathrm{~g} \mathrm{~kg}^{-1}$. Increased rate of $\mathrm{N}$ application reduced the crude fibre (cellulose) content. Crude fibre (cellulose) content was 338.35 and $279.0 \mathrm{~g} \mathrm{~kg}^{-1}$ at the lowest and highest $\mathrm{N}$ rates, respectively.

Nitrogen application correlated strongly $(\mathrm{r}>0.9)$ and significantly $(\mathrm{P}=0.01)$ with dry matter yield, chemical and mineral composition (Table 5). Positive correlation coefficients were obtained between $\mathrm{N}$ application and dry matter yield, crude protein, ash, fat, ( $\mathrm{r}=0.999^{* *}, 0.988^{* *}, 0.988^{* *}, 0.998^{* *}$, respectively) $(\mathrm{P}=0.01)$. Negative correlation coefficients were obtained between $\mathrm{N}$ application and crude fibre (cellulose), $\left(\mathrm{r}=-0.998^{* *},(\mathrm{P}=0.01)\right.$. Regression equations relating rate of $\mathrm{N}$ fertilizer to yield and quality components are given in Table 5.

Table 5. Correlation coefficients between forage yield and quality of Cynosuretum cristati meadow type and different rates of nitrogen fertilizer

\begin{tabular}{lll}
\hline \multicolumn{1}{c}{ Yield and quality } & \multicolumn{1}{c}{$\begin{array}{c}\text { Correlation } \\
\text { coefficients }\end{array}$} & Regression equation \\
\hline $\mathrm{DMY}$ & $\mathrm{r}=0.999^{* *}$ & $\mathrm{Y}=2.393 * \mathrm{X}^{\wedge} .1207$ \\
$\mathrm{CP}-\mathrm{SP}$ & $\mathrm{r}=0.988^{* *}$ & $\mathrm{Y}=79.91729+.3569967 \mathrm{X}+-1.248333 \mathrm{E}-04$ \\
Ash & $\mathrm{r}=0.988^{* *}$ & $\mathrm{Y}=53.805 * \mathrm{E} \wedge 1.648 \mathrm{E}-0.3 * \mathrm{X}$ \\
Fat & $\mathrm{r}=0.998^{* *}$ & $\mathrm{Y}=14.2284+.2113745 \mathrm{X}+-6.021365 \mathrm{E}-04 \mathrm{X}^{\wedge} 2$ \\
$\mathrm{CF}$ & $\mathrm{r}=-0.998^{* *}$ & $\mathrm{Y}=338.6634 * \mathrm{E}^{\wedge}-1.219319 \mathrm{E}-03 * \mathrm{X}$ \\
$(* *=\mathrm{P}=0.01)$ & &
\end{tabular}




\title{
Conclusions
}

All levels of nitrogen fertilizers had a favorable effect on the yield and quality. The maximum yield was obtained with $160 \mathrm{~kg} \mathrm{ha}^{-1}$ nitrogen, amounting to $4.44 \mathrm{t} \mathrm{ha}^{-1}$ for two years, which was an increase of 2,04 $\mathrm{t} \mathrm{ha}^{-1}$ or $85.0 \%$ over the control. The fertilizers have also changed botanical composition of the Cynosuretum cristati plant association. By the increase of nitrogen fertilization level, the quantity of grass, especially those of a better quality, is improved, while legumes and other herbages are decreased. Increasing rate of $\mathrm{N}$ application increased the protein, ash, fat content; on average, and reduced the cellulose content. Nitrogen application correlated strongly $(\mathrm{r}>0.9)$ and significantly $(\mathrm{P}=0.01)$ with dry matter yield and chemical composition. Positive correlation coefficients were obtained between $\mathrm{N}$ application and dry matter yield, crude protein, ash, fat, $\left(\mathrm{r}=0.999^{* *}, 0.988^{* *}, 0.988^{* *}, 0.998^{* *}\right.$, respectively) $(\mathrm{P}=0.01)$. Negative correlation coefficients were obtained between $\mathrm{N}$ application and crude fibre (cellulose), $\left(\mathrm{r}=-0.998^{* *},(\mathrm{P}=0.01)\right.$.

\section{POVEZANOST IZMEĐU PRODUKTIVNOSTI I KVALITETA KRME TRAVNJAKA CYNOSURETUM CRISTATI I RAZLIČITIH NIVOA AZOTNOG ĐUBRIVA}

\author{
S. Vučković, A. Simić, N. Đorđević
}

Rezime

Svi nivoi azotnog đubriva su imali pozitivan uticaj na prinos i kvalitet krme. Najveći prinos je ostvaren sa $160 \mathrm{~kg} \mathrm{ha}^{-1}$ azota, dajući 4,44 $\mathrm{t} \mathrm{ha}^{-1}$ za dve godine, što je bilo povećanje za $2,04 \mathrm{t} \mathrm{ha}^{-1}$ ili $85 \%$ više od kontrole. Đubriva su takođe uticala na promenu botaničkog sastava biljne asocijacije Cynosuretum cristati. Sa povećanjem nivoa azotnog đubriva, količina trava, naročito boljeg kvaliteta, je uvećana, dok su leguminoze i druge vrste smanjene. Povećanje količine primenjenog azota je uvećalo sadržaj proteina, pepela, masti i smanjilo sadržaj celuloze. Primenjeni azot je u jakoj korelacionoj vezi $(r>0.9)$ i velike značajnosti $(\mathrm{P}=0.01)$ sa prinosom suve materije $\mathrm{i}$ hemijskim sastavom. Pozitivan korelacioni koeficijent je dobijen između primenjenog $\mathrm{N}$ i prinosa suve materije, sirovih proteina, pepela, masti $\left(\mathrm{r}=0.999 * *, 0.988^{* *}, 0.988^{* *}\right.$, $0.998^{* *}$, redom $)(\mathrm{P}=0.01)$. Negativan korelacioni koeficijent je dobijen između primenjenog $\mathrm{N}$ i celuloznih vlakana $\left(\mathrm{r}=-0.998^{* *}\right)(\mathrm{P}=0.01)$.

Ključne reči: hemijski sastav, prinos $\mathrm{SM}$, primenjeni $\mathrm{N}$, povezanost

\section{References}

1. ALIBEGOVIĆ - GRBIĆ, S. and ČIVIĆ H. (2003): Effects of N - fertilisation and stage of growth on the dry matter and protein yields of grassland. Grassland Science in Europe, Volume 8, 2003, pages 160-162

2. CHAMBLE D. S., LOVVORN R. L. and WOODHOUSE W. (1953) The influence of Nitrogen Fertilization and Management on Yield, Botanical Composition and Nitrogen Content of a Permanent Pasture. Agronomy Journal, 45 (4).

3. LAVRENČIČ, A. and OREŠNIK, A. (2002): Relationships between grass forage chemical composition and codified morphological stages. Grassland Science in Europe, Volume 7, 2002, pages 140-141.

4. SIMA, N. and PACURÂR, F. (2002): Quality of forage obtained from a mountain pasture as influenced by harvesting phenophase and managment. Grassland Science in Europe, Volume 7, 2002, pages 160161.

5. VUCKOVIĆ S., SIMIĆ A., ĆUPINA B., STOJANOVIĆ I., STANISAVLJEVIĆ, R., VOJIN S. i DUBLJEVIĆ, R. (2004): Uticaj đubrenja azotom na produktivnost pasnjaka Cynosuretum cristati na Sjeničko-pešterskoj visoravni, Acta Agriculture Serbica, Vol. IX, 17 str. 279-287. 